\title{
Wind pumps for irrigating greenhouse crops: Comparison in different socio-economical frameworks
}

\author{
Rodrigo Díaz-Méndez , Adnan Rasheed, Manuel Peillón , \\ Alicia Perdigones . Raúl Sánchez , Ana M. Tarquis , \\ José L. García-Fernández
}

Keywords:

Water pumping

Wind pumps

Photovoltaic installations

Levelised cost of energy
A simple methodology was used to compare the economic feasibility of wind pump technology, solar photovoltaic pumping, diesel generators, and connection to the electrical grid to provide energy for pumping irrigation water in commercial greenhouses in Spain, Cuba and Pakistan (countries with different developmental backgrounds). The analysis took into account wind resources, distance to the grid, water storage tank volume requirements, and planting dates. Comparisons were made in terms of the levelised cost of energy associated with each system. For all three countries, if a grid connection was already in place, installing wind pumps would be economically unwise. Where no grid connection exists, the distance to the grid and the wind resource available are key factors to be taken into consideration when deciding between options: a $10 \%$ increase in the average wind speed is equivalent to a $20 \%$ reduction in the distance to the grid in terms of costs return. Finally, the water elevation has a major influence on the economic feasibility of wind pump technology, much more than, for example, on solar photovoltaic pumping technology. The results reveal that, generally, the critical factors to consider when making energy management decisions differ depending between countries. In Spain, the proximity of the electrical grid makes the connection to it the best option. In Pakistan, scarce wind resources are a serious limiting factor. Cuba, however, has good wind resources; water elevation, distance to the grid and water storage needed are the critical factors when determining the economic feasibility of wind pumping there. 


\begin{tabular}{|c|c|c|c|}
\hline \multicolumn{2}{|c|}{ Nomenclature } & $\mathrm{Kc}$ & crop coefficient, dimensionless \\
\hline & & L & distance, $\mathrm{km}$ \\
\hline AO & $\begin{array}{l}\text { annual energy output, } \mathrm{m} \text { water (with water } \\
\text { volume understood to represent potential energy) }\end{array}$ & LCOE & levelised cost of energy, $€ \mathrm{~m}^{-3}$ water \\
\hline & annual diesel pump set maintenance cost, fraction & & period of analysis, years \\
\hline$C_{m, p y}$ & $\begin{array}{l}\text { annual alesel pump set maintenance cost, Iraction } \\
\text { annual photovoltaic maintenance cost, fraction }\end{array}$ & O\&M & annual operation and maintenance cost, $€$ \\
\hline & annual grid connection maintenance cost, fraction & & power, W \\
\hline $\mathrm{C}_{\mathrm{m}, \mathrm{g}}$ wind & annual wind pump maintenance cost, fraction & $p_{d s}$ & market price of diesel, $€ 1^{-1}$ \\
\hline $\begin{array}{l}\text { Um, wind } \\
d\end{array}$ & discount rate, fraction & & market price of electricity, $€ \mathrm{~kW}^{-1} \mathrm{~h}^{-1}$ \\
\hline$D$ & days per year, days year ${ }^{-1}$ & $\mathrm{Q}(\mathrm{H})$ & water discharge for height $H, 1 \mathrm{~min}^{-1}$ \\
\hline EC & energy demand for pumping, $\mathrm{kWh}_{\mathrm{year}} \mathrm{y}^{-1}$ & $r_{\mathrm{ds}}$ & annual diesel price increase rate, fraction \\
\hline EP & minimum power, $\mathrm{kW}$ & $r_{\mathrm{e}}$ & annual electricity price increase rate, fraction \\
\hline ETc & outside crop evapotranspiration requirement, & $r_{\mathrm{if}}$ & inflation rate, fraction \\
\hline & $\mathrm{mm}_{\text {day }}{ }^{-1}$ & & lifetime cycle of diesel pump set, year \\
\hline $\mathrm{ET}_{0}$ & reference crop evapotranspiration, mm day ${ }^{-1}$ & $t_{\mathrm{op}}$ & operating time, h day ${ }^{-1}$ \\
\hline $\mathrm{ETr}$ & $\begin{array}{l}\text { greenhouse tomato crop evapotranspiration, } \\
\mathrm{mm} \mathrm{day}^{-1}\end{array}$ & $\begin{array}{l}t_{\mathrm{PV}} \\
t_{\text {wind }}\end{array}$ & $\begin{array}{l}\text { lifetime cycle of solar photovoltaic system, year } \\
\text { lifetime cycle of wind pump, year }\end{array}$ \\
\hline FCR & fixed charge rate, fraction & V & water volume, $\mathrm{m}^{3}$ \\
\hline$g$ & gravitational acceleration, $9.8 \mathrm{~m} \mathrm{~s}^{-2}$ & W & wind velocity, $\mathrm{m} \mathrm{s}^{-1}$ \\
\hline $\mathrm{H}$ & water elevation, $m$ & WN & annual tomato water needs, $\mathrm{m}^{3}$ year ${ }^{-1}$ \\
\hline I & initial investment, $€$ & $\sigma$ & standard deviation \\
\hline$I_{\mathrm{ds}}$ & diesel pumpset capital cost, $€ \mathrm{~W}^{-1}$ & $\rho$ & water density, $\mathrm{kg} \mathrm{m}^{-3}$ \\
\hline$I_{\mathrm{g}}$ & grid connection capital cost, $€ \mathrm{~km}^{-1}$ & $\eta$ & pumping efficiency, dimensionless \\
\hline$I_{\mathrm{PV}}$ & solar photovoltaic capital cost, $€ \mathrm{~W}^{-1}$ & $\eta_{\mathrm{ds}}$ & average efficiency of diesel pump, dimensionless \\
\hline$I_{\mathrm{t}}$ & storage tank capital cost $V<30 \mathrm{~m}^{3}, € \mathrm{~m}^{-3}$ & $\eta_{\mathrm{PV}}$ & average efficiency of solar photovoltaic pump set \\
\hline $\begin{array}{l}I_{\mathrm{T}} \\
I_{\text {wind }}\end{array}$ & $\begin{array}{l}\text { storage tank capital cost } V>30 \mathrm{~m}^{3}, € \mathrm{~m}^{-3} \\
\text { wind pump capital cost, } € \text { pump }\end{array}$ & $\eta_{\text {wind }}$ & average efficiency of wind pump, dimensionless \\
\hline
\end{tabular}

\section{Introduction}

Water management plays a decisive role in agricultural development: an adequate, economic water supply at the crop/farm level is vitally important (Rodrigues \& Pereira, 2009). Energy and water supply management are commonly bound up with one another (Rodríguez, López, Carrillo, Montesinos, \& Camacho, 2009), and using wind pumps for irrigation etc. is an energy option commonly contemplated.

Traditional direct shaft wind pumps, such as American multi-blade windmills, have seen little development in recent decades; indeed, these pumps have given reliable service since the early 20th century (Mathew, 2006, 241 pp.). However, different types of wind pump system have been developed for different applications. Windmills using piston pumps are now the most common worldwide (Vázquez, 2004).

The main alternatives to wind energy for pumping are electricity from the grid, diesel engine systems, and solar photovoltaic (PV) energy (Al Malki, Al Amri, \& Al Jabri, 1998; AlSmairan, 2012; Ghoneim, 2006; Koner, 1995; Mustafa, 2001; Parida, Iniyan, \& Goic, 2011; Ramos \& Ramos, 2009). The feasibility of connection to the electrical grid depends mainly on the distance to it and the connection costs. Diesel engine systems are less expensive and easier to assemble, but require a regular supply of fuel and lubricant, frequent maintenance and more user attention. Solar PV energy, which uses a simple and safe technology, is initially expensive but requires little maintenance (Walker \& Jenkins, 1997). Hybrid systems might also be used (Jaramillo, Borja, \& Huacuz, 2004). Studies that have compared the performance of wind and solar technologies (Vick \& Clark, 1996) have shown the former to be a better choice under the conditions in which the comparisons were made (annual average wind speed of $5.73 \mathrm{~m} \mathrm{~s}^{-1}$ at $10 \mathrm{~m}$ height, annual average solar radiation - latitude tilt $-2098 \mathrm{kWh} \mathrm{m}^{-2}$, $30 \mathrm{~m}$ pumping depth). However, further studies are required that take into account both the water demand, and the developmental conditions of the country and production sector in which the water is needed.

The countries contemplated in the present work were Cuba, Pakistan and Spain - nations with very different developmental backgrounds and socioeconomic frameworks - and the production sector requiring an energy supply for irrigation was the greenhouse agricultural sector.

In Cuba, this is still a small sector; the latest report reveals the area occupied by commercial greenhouses to be only 42 ha (Ajete, Bonet, Duarte, Vargas, \& Pérez, 2011), largely producing horticultural products. However, this agrotechnology is of great interest in Cuba, and there are plans to increase the sector size to meet demands of the tourism industry for fresh vegetables. One of the problems faced is the supply of energy to these greenhouses since the country electrical grid does not extend everywhere, and at times the supply quality is poor. The official price of electricity is similar to that in other countries, but these problems make the use of small, renewable energy facilities at the site of consumption quite attractive.

In Pakistan, the agricultural greenhouse sector is growing rapidly, and although it is not one of the country most important industries, it is firmly established and has high 
growth expectations. The electricity grid is well developed, but it does not cover all agricultural land in the country. The energy market price is low compared to the world average.

In Spain, the greenhouse industry, combined with the agricultural processing industry, is one of the most important in the country, and has an exporting tradition. The current area occupied by greenhouses producing ornamental plants and vegetables is 60,482 ha (MAGRAMA, 2012, pp. 1-46). The main production area is in Almería, a south-eastern region of Spain, which has one of the largest concentrations of greenhouses in the world. Energy supply infrastructures are highly developed and cover virtually all of the country agricultural land. The market price of electrical energy is, however, high compared to the world average.

The three countries also have different wind resources. The Department of Energy of the United States has published documentation, measurements and wind maps for Cuba and Pakistan (U.S. Department of Energy, 2012) at a height of $50 \mathrm{~m}$, and the Spanish Institute for Diversification and Energy Efficiency (IDAE) has published the same for Spain at heights of $30 \mathrm{~m}$ and $80 \mathrm{~m}$ (IDAE, 2011). Wind speed measurements are commonly made at different heights above ground level; information for other heights can be extrapolated from the available data using logarithmic expressions (IDAE, 2011).

The aim of the present work was to assess the feasibility of using wind pump technology for irrigation by the greenhouse sector in these countries and the related critical factors, within the context of their developmental backgrounds and their energy supply characteristics.

\section{Material and methods}

\subsection{Processing of wind data}

Three representative locations, one in each country, were selected from the available information on the wind resource in the three countries (Spain: IDAE, 2011; Cuba and Pakistan: U.S. Department of Energy, 2012). Table 1 shows the location and measuring equipment available at the meteorological stations at the three sites selected. The wind data from these stations have been treated according to the methodology developed by Peillón, Sánchez, Tarquis, and García (2013) to generate monthly wind velocity frequency histograms. This methodology uses the Weibull II distribution function for estimating the wind speed distribution function. The mean values of the two parameters $a$ (shape parameter) and $b$ (scale parameter) characterising the Weibull distribution, were used to simulate the 'average wind situation'; moreover, the 'high wind situation' and 'low wind situation' were evaluated by considering the standard deviation $\sigma,(a+\sigma a / b+\sigma b)$ and $(a-\sigma a / b-\sigma b)$, respectively. The characteristics of the wind resource of most of the possible locations in each country would fall within the range of the high-to-low wind situations.

\subsection{Wind pumps and wind speeds}

The "Veleta", "Delta junior" (Vázquez, 2004) and "Poldaw" (Villiers Aqua Engineering, 2013) windmill models are used in the three studied countries. These models are technologically similar and a single, comprehensive model representing all three types was contemplated. This consisted of a wind pump with a $6 \mathrm{~m}$-high conical tower. The rotor was $2.2 \mathrm{~m}$ in diameter, had eight blades, and required a wind velocity of $2.77 \mathrm{~m} \mathrm{~s}^{-1}$ to start moving. This same comprehensive model has been used in previous work (Peillón et al., 2013). Only wind velocities of $>2.77 \mathrm{~m} \mathrm{~s}^{-1}$ to start up, and lower than the maximum recommended safe wind speed $\left(10.8 \mathrm{~m} \mathrm{~s}^{-1}\right)$ were considered in calculations of the discharge pumped.

\subsection{Calculation of the flow produced by the wind pump}

The discharge by the wind pump under different elevation and wind speed conditions was calculated using the following equations: $\left(Q(H)\right.$, water discharge for height $H, 1 \mathrm{~min}^{-1} ; H$, water elevation, $\mathrm{m} ; \mathrm{W}$, wind velocity, $\mathrm{m} \mathrm{s}^{-1}$ ):

$Q(15)=16.00 \cdot \ln W-13.47$

$Q(20)=9.13 \cdot \ln W-7.34$

$\mathrm{Q}(25)=7.31 \cdot \ln W-6.08$

These equations have been used in a previous work (Peillón et al., 2013). The water elevation $(H)$ was defined as the difference in height between the free level of water in the well and the end of the tube depositing water into the tank. The equations were obtained from the discharged pumped data at different wind speeds and elevations provided by the manufacturers. Regression analysis of the discharge pumped data is the basis for Equations (1)-(3), correlating the discharge pumped at the given elevation with the wind speed.

The empirical equations described above were used to calculate the discharge produced by the pumps using the average wind speed binned every $3 \mathrm{~h}$ within the operating wind speed range of $2.77-10.8 \mathrm{~m} \mathrm{~s}^{-1}$. This was accumulated to

Table 1 - Characteristics of the meteorological stations at the three chosen sites.

\begin{tabular}{|c|c|c|c|c|}
\hline Location & Latitude/Longitude & Time series & Wind speed sensor & $\begin{array}{l}\text { Height of the wind } \\
\text { speed sensor }\end{array}$ \\
\hline Venezuela, Cuba (78346 meteorological station) & $21^{\circ} 47^{\prime} \mathrm{N} / 78^{\circ} 47^{\prime} \mathrm{W}$ & $1970-2008$ & $\begin{array}{l}\text { Optoelectronic cup } \\
\text { anemometer }\end{array}$ & $10.0 \mathrm{~m}$ \\
\hline $\begin{array}{l}\text { Faisalabad, Pakistan (Crop physiology } \\
\text { Department, University of Agriculture) }\end{array}$ & $31^{\circ} 26^{\prime} \mathrm{N} / 73^{\circ} 06^{\prime} \mathrm{E}$ & $2010-2012$ & $\begin{array}{l}\text { Campbell 034B cup } \\
\text { anemometer }\end{array}$ & $3.0 \mathrm{~m}$ \\
\hline $\begin{array}{l}\text { Madrid, Spain (Agricultural Engineering } \\
\text { School, Technical University of Madrid) }\end{array}$ & $40^{\circ} 26^{\prime} \mathrm{N} / 3^{\circ} 44^{\prime} \mathrm{W}$ & $1999-2001$ & $\begin{array}{l}\text { Geónica UV-2000 cup } \\
\text { anemometer }\end{array}$ & $2.5 \mathrm{~m}$ \\
\hline
\end{tabular}


Table 2 - Typical planting dates and duration of the tomato crop in each country (Gamacho, 2003; Pino, Terry, León, \& Soto, 2003).

\begin{tabular}{lcccc} 
Location & Planting date: autumn crop & Duration & Planting date: spring crop & Duration \\
\hline Cuba & September & 97 days & February & 110 days \\
Pakistan & July/August/September & 135 days & December/January & 165 days \\
Spain & August & 135 days & January & 165 days \\
\hline
\end{tabular}

obtain the daily and monthly discharge pumped by high, average or low windspeed distributions at each location.

\subsection{Determination of crop water needs}

Evapotranspiration can be determined in different ways (Cammalleri et al., 2010; Cammalleri, Ciraolo, Minacapilli, \& Rallo, 2013; Verstraeten, Veroustraete, \& Feyen, 2008). In the present work, the evapotranspiration for a tomato crop inside the greenhouse (ETr) was determined using the methodology proposed by Chapagain and Orr (2009), according to which the outside crop evapotranspiration requirement (ETc[t] $\mathrm{mm}$ day $\left.^{-1}\right)$ is calculated using the crop coefficient (Kc[t]) and reference crop evapotranspiration $\left(\mathrm{ET}_{\mathrm{o}}[\mathrm{t}] \mathrm{mm}\right.$ day $^{-1}$ ) at the location for the respective growth period $[t]$ :

$$
\operatorname{ETc}[t]=\mathrm{Kc}[\mathrm{t}] \cdot \mathrm{ET}_{0}[\mathrm{t}]
$$

Compared to irrigated crops outdoors, the maximum seasonal evapotranspiration of greenhouse horticultural crops is relatively low due to the smaller evaporative demand, the result of being inside away from moving air, etc. According to Chapagain and Orr (2009), the greenhouse evapotranspiration is some $70-80 \%$ of the ETc for an outdoor tomato crop in tropical and subtropical climates with a dry winter. In this work, greenhouse tomato evapotranspiration $E \operatorname{Tr}[t]$ was calculated from the outside tomato evapotranspiration ETc $[t]$, assuming a $70 \%$ reduction in evapotranspiration for all three wind scenarios.

$\mathrm{ETr}[\mathrm{t}]=0.70 \mathrm{ETc}[\mathrm{t}]$

Table 2 shows the typical planting dates and duration of tomato growth stages in each of the studied countries. The annual water needs were then calculated for each location using Equation (5).

\subsection{Determination of energy and power needs}

Pumping simulations for irrigation were performed for greenhouses of 1000 and $10,000 \mathrm{~m}^{2}$. Greenhouse size influences the energy demand and, therefore, the technology required to supply irrigation needs. The following systems were studied in each case:

- $1000 \mathrm{~m}^{2}$ greenhouse, pumping with a diesel generator, a wind pump, or a solar photovoltaic pump.

- 10,000 $\mathrm{m}^{2}$ greenhouse, pumping connected to the grid, a solar PV pump, a diesel generator, or a wind pump.

After calculating the annual water needs of the crop (WN, $\mathrm{m}^{3}$ year $^{-1}$ ), the energy demand for pumping (EC, $\mathrm{kWh}_{\mathrm{year}}{ }^{-1}$ ), and the minimum power required (EP, $\mathrm{kW}$ ), were calculated using the following equations:
$\mathrm{EC}=\frac{\rho \cdot \mathrm{g} \cdot \mathrm{WN} \cdot \mathrm{H}}{3.610^{6} \cdot \eta}$

$E P=\frac{E C}{D \cdot t_{o p}}$

where $\rho$ is the water density expressed in $\mathrm{kg} \mathrm{m}^{-3}, \mathrm{~g}$ is the gravitational acceleration $\left(9.8 \mathrm{~m} \mathrm{~s}^{-2}\right), H$ is the water elevation required $(\mathrm{m}), \eta$ is the pumping efficiency (dimensionless), $D$ is the number of days in the year, and $t_{\text {op }}$ is the operating time expressed in $\mathrm{h}$ per day.

A fixed water elevation of $15 \mathrm{~m}$ was selected. The power and energy required for this elevation are technology-specific; their calculation is described in the following sections. The minimum power was calculated contemplating an energy demand over $4 \mathrm{~h}$ per day $\left(t_{o p}\right)$ and 365 days per year $(D)$. This ratio allows the calculation of the maximum power requirements of the technology to be used, and therefore the investment required (of course, the equipment will not always be run at the maximum setting). Table 3 summarises the variables assumed in the technical and financial assessment of the different technologies for irrigation water pumping.

\subsection{Technical and economic assessment of the technologies}

The concept of the levelised cost of energy (LCOE) (Short, Packey, \& Holt, 1995) was used to assess the ability of each technology to meet annual water needs in financial terms. The LCOE represents the cost per unit of energy that, if held constant over the analysis period, would provide the same net present revenue value as the net present value cost of the system. It is calculated as follows:

$\mathrm{LCOE}=\frac{\mathrm{I} \cdot \mathrm{FCR}+\mathrm{O} \& \mathrm{M}}{\mathrm{AO}}$

Table 3 - Variables and values used in the technical and financial assessment of the different technologies for irrigation water pumping.

\begin{tabular}{|c|c|c|c|}
\hline Parameter & Symbol & Unit & Value \\
\hline Water density & $\rho$ & $\mathrm{kg} \mathrm{m}^{-3}$ & 1000 \\
\hline Acceleration due to gravity & $g$ & $\mathrm{~m} \mathrm{~s}^{-2}$ & 9.8 \\
\hline $\begin{array}{l}\text { Average efficiency of diesel } \\
\text { pump }\end{array}$ & $\eta_{\mathrm{ds}}$ & Dimensionless & 0.40 \\
\hline $\begin{array}{l}\text { Average efficiency of PV } \\
\text { pump set }\end{array}$ & $\eta_{\mathrm{PV}}$ & Dimensionless & 0.39 \\
\hline $\begin{array}{l}\text { Average efficiency of wind } \\
\text { pump }\end{array}$ & $\eta_{\text {wind }}$ & Dimensionless & 0.25 \\
\hline $\begin{array}{l}\text { Lifetime cycle of diesel } \\
\text { pump set }\end{array}$ & $t_{d s}$ & Year & 10 \\
\hline Lifetime cycle of PV system & $t_{\mathrm{PV}}$ & Year & 20 \\
\hline Lifetime cycle of wind pump & $t_{\text {wind }}$ & Year & 20 \\
\hline
\end{tabular}


Table 4 - Economic variables used in the financial evaluation of the different technologies for irrigation water pumping. The maintenance cost is expressed as a fraction of the capital cost.

\begin{tabular}{|c|c|c|c|c|c|}
\hline \multirow[t]{2}{*}{ Parameter } & \multirow[t]{2}{*}{ Symbol } & \multirow[t]{2}{*}{ Unit } & Cuba & \multirow{2}{*}{$\frac{\text { Spain }}{\text { Value }}$} & \multirow{2}{*}{$\begin{array}{c}\text { Pakistan } \\
\text { Value }\end{array}$} \\
\hline & & & Value & & \\
\hline Annual diesel pump set maintenance cost & $\mathrm{C}_{\mathrm{m}, \mathrm{ds}}$ & Fraction & 0.06 & 0.08 & 0.10 \\
\hline Annual PV maintenance cost & $\mathrm{C}_{\mathrm{m}, \mathrm{PV}}$ & Fraction & 0.01 & 0.02 & 0.01 \\
\hline Annual wind pump maintenance cost & $\mathrm{C}_{\mathrm{m}, \text { wind }}$ & Fraction & 0.02 & 0.03 & 0.02 \\
\hline Annual grid connection maintenance cost & $\mathrm{C}_{\mathrm{m}, \mathrm{g}}$ & Fraction & 0.02 & 0.02 & 0.02 \\
\hline Inflation rate & $r_{\text {if }}$ & Fraction & 0.03 & 0.03 & 0.03 \\
\hline Annual electricity price increase rate & $r_{e}$ & Fraction & 0.05 & 0.05 & 0.05 \\
\hline Annual diesel price increase rate & $r_{\mathrm{ds}}$ & Fraction & 0.05 & 0.05 & 0.05 \\
\hline Discount rate & $d$ & Fraction & 0.05 & 0.05 & 0.05 \\
\hline Market price of diesel & $p_{\mathrm{ds}}$ & $€ 1^{-1}$ & 0.90 & 0.93 & 0.81 \\
\hline Market price of electricity & $p_{\mathrm{e}}$ & $€ \mathrm{~kW}^{-1} \mathrm{~h}^{-1}$ & 0.18 & 0.16 & 0.11 \\
\hline
\end{tabular}

where $I$ is the initial investment, O\&M represents the annual operation and maintenance costs, $\mathrm{AO}$ is the annual energy output (understanding water volume as defining the potential energy requirement; therefore the LCOE is expressed as $€ \mathrm{~m}^{-3}$ water), and FCR is the fixed charge rate. The FCR is the factor by which the capital investment is multiplied to obtain the annual capital investment cost. It is calculated as follows:

$\mathrm{FCR}=\frac{d \cdot(1+d)^{N}}{(1+d)^{N}-1}$

where $d$ is the annual discount rate and $N$ the period of analysis, in years. No insurance costs or taxes were contemplated in this study.

Table 4 shows the investment data and economic variables required for calculating the real LCOE of each technology for each country.

Table 5 shows the information required for calculating the different investment costs as a function of the variables considered.

\subsection{Sensitivity analysis}

A sensitivity analysis for the following variables was undertaken:

- Wind speed (alternatives described in Section 2.1)

- Distance to the electrical grid

- Water storage tank volume

- Crop development dates (see Table 2)

For the set of simulations, a basic case study was considered as the starting point of analysis. Table 6 shows the different conditions contemplated. Since the use of wind and PV pumping entails the use of larger water storage tanks, a specific sensitivity analysis was performed for water storage volume to determine the profitability of the these technologies as a function of the number of calm/cloudy days.

In the initial analysis, the greenhouse was considered to be already connected to the electrical grid. Therefore, water pumping only implied the need for an alternative electrical power source. In all other analyses, the greenhouse was considered to have no present electricity supply.

\section{Results and discussion}

The results of the initial analysis showed that, for all countries, the installation of wind pump and PV technologies would not be economically advantageous. The LCOE associated with the use of the conventional electrical supply was lower than that of either a wind or PV energy supply. The water storage tank required to guarantee the water supply for wind and PV pumping increased the costs, wiping out any economic return.

In the remaining analyses, the greenhouse was considered to have no grid connection in place. Thus, conventional or renewable technologies could be selected without constraints. Tables 7 and 8 show the LCOE values associated with their use, measured in equivalent hours per year. The water elevation has a larger influence on the wind pump than on the PV technology (Fig. 1). Wind resources would be a clear limiting factor in areas of Spain and Pakistan; the wind in Cuba is usually stronger (the "average wind situation" is $1650 \mathrm{~h}$ year $^{-1}$ at the chosen location in Spain, $1705 \mathrm{~h} \mathrm{year}^{-1}$ in Pakistan, and $2470 \mathrm{~h}_{\text {year }}^{-1}$ in Cuba).

Table 5 - Cost variables for the different technologies as function of power $P(W)$, distance to the grid $L(k m)$, and water volume $V\left(\mathrm{~m}^{3}\right)$.

\begin{tabular}{|c|c|c|c|c|c|}
\hline \multirow[t]{2}{*}{ Investment cost } & \multirow[t]{2}{*}{ Symbol } & \multirow[t]{2}{*}{ Unit } & Cuba & Spain & Pakistan \\
\hline & & & Value & Value & Value \\
\hline Wind pump capital cost & $I_{\text {wind }}$ & $€ \mathrm{pump}^{-1}$ & 2082 & 3366 & 3072 \\
\hline PV capital cost & $I_{P V}$ & $€ W^{-1}$ & $3.04 \times P(W)+2022$ & $2.02 \times P(W)+2829$ & $2.19 \times P(W)+2024$ \\
\hline Diesel pumpset capital cost & $I_{\mathrm{ds}}$ & $€ \mathrm{~W}^{-1}$ & 0.65 & 0.97 & 0.72 \\
\hline Grid connection capital cost & $I_{\mathrm{g}}$ & $\in \mathrm{km}^{-1}$ & $8000 \times L(\mathrm{~km})+950$ & $10,000 \times L(\mathrm{~km})+1500$ & $7000 \times L(\mathrm{~km})+1150$ \\
\hline Storage tank capital cost $V<25 \mathrm{~m}^{3}$ & $I_{t}$ & $€ \mathrm{~m}^{-3}$ & $267 \times V\left(m^{3}\right)+331$ & $278 \times V\left(\mathrm{~m}^{3}\right)+508$ & $269 \times V\left(m^{3}\right)+371$ \\
\hline Storage tank capital cost $V>25 \mathrm{~m}^{3}$ & $\mathrm{I}_{\mathrm{T}}$ & $\in \mathrm{m}^{-3}$ & $71 \times V\left(m^{3}\right)+5366$ & $70.83 \times V\left(\mathrm{~m}^{3}\right)+5806$ & $74 \times V\left(m^{3}\right)+5474$ \\
\hline
\end{tabular}




\begin{tabular}{lccc}
\multicolumn{3}{c}{ Table $\mathbf{6}$ - Basic case study data. } & \\
\hline Condition & Unit & $\begin{array}{c}1000 \mathrm{~m}^{2} \\
\text { greenhouse }\end{array}$ & $\begin{array}{c}10,000 \mathrm{~m}^{2} \\
\text { greenhouse }\end{array}$ \\
\hline $\begin{array}{c}\text { Distance to } \\
\text { grid }\end{array}$ & $\mathrm{km}$ & 1 & 1 \\
$\begin{array}{c}\text { Water storage } \\
\text { tank size }\end{array}$ & $\mathrm{m}^{3}$ & 10 & 100 \\
$\begin{array}{c}\text { Water } \\
\text { elevation }\end{array}$ & $\mathrm{m}$ & 15 & 15 \\
\hline
\end{tabular}

Figure 2 shows the LCOE values for Pakistan and Cuba for different technologies and different greenhouse sizes. Greenhouse size is a factor to be considered in any choice of energy technology. The wind pump LCOE is closer to that of diesel pumping in Cuba for a greenhouse of $1000 \mathrm{~m}^{2}$, than for a greenhouse of $10,000 \mathrm{~m}^{2}$. In the latter case, the LCOE for diesel is approximately half that of the renewable resources while in the former, it is $70 \%$ of the value. Thus, wind pumping might be more suitable for smaller greenhouses, depending on the wind resources available and the price of diesel.

The results showed that the distance to the grid is a key factor to consider when thinking of adopting wind pumps (Fig. 3). However, the wind resources available and the wind speed are even more important factors (a 10\% increase in the average wind speed is equivalent to a $20 \%$ reduction in the distance to the grid). Distances to the grid of under $1000 \mathrm{~m}$ were, in many cases (Fig. 3), associated with a LCOE for grid connection that was lower than that associated with wind pumping. Thus, if the electrical grid is only a short distance away, wind pumping is ruled out as a viable alternative. This would be particularly true for Spain. However, in areas of Cuba or Pakistan, distances to the grid might be larger, making wind pumping a viable option.

The volume of water that needs to be stored, so that irrigation can proceed during periods without wind or sun, strongly affects the associated LCOEs (Fig. 4). Typically, a system would require three days-worth of stored water. If the wind resources available made it necessary to store water for eight days, the calculated wind pump LCOE might double (see values for Pakistan in Fig. 4).

Finally, the within-country relationship between the periods with high wind velocities and periods with high tomato prices was examined. The influence of the wind monthly behaviour has already been reported by Peillón et al. (2013): in

Table 7 - PV pumping levelised cost of energy $\left(€ \mathrm{~m}^{-3}\right)$ as a function of the solar resource expressed in solar equivalent hours (h year ${ }^{-1}$ ) per country and water elevation for a $10,000 \mathrm{~m}^{2}$ greenhouse.

\begin{tabular}{llllllll}
$H(\mathrm{~m})$ & Country & \multicolumn{5}{c}{ Solar resource (Solar equivalent } \\
& & & \multicolumn{6}{c}{ hours per year) } \\
\cline { 3 - 8 } & & 1575 & 1710 & 1840 & 1975 & 2100 & 2230 \\
\hline 15 & Pakistan & 0.40 & 0.40 & 0.39 & 0.39 & 0.38 & 0.38 \\
15 & Spain & 0.41 & 0.40 & 0.40 & 0.39 & 0.38 & 0.38 \\
15 & Cuba & 0.36 & 0.36 & 0.36 & 0.35 & 0.35 & 0.34 \\
25 & Pakistan & 0.41 & 0.41 & 0.40 & 0.40 & 0.39 & 0.39 \\
25 & Spain & 0.41 & 0.41 & 0.41 & 0.40 & 0.40 & 0.40 \\
25 & Cuba & 0.37 & 0.37 & 0.36 & 0.36 & 0.36 & 0.35 \\
\hline
\end{tabular}

Table 8 - Wind pump levelised cost of energy $\left(€ \mathrm{~m}^{-3}\right)$ as a function of the wind resource expressed in equivalent hours ( $h$ year ${ }^{-1}$ ) per country and water elevation for a $10,000 \mathrm{~m}^{2}$ greenhouse.

$H(\mathrm{~m})$ Country Wind resource (Wind equivalent

\begin{tabular}{llccccc} 
& & \multicolumn{5}{c}{ hours per year) } \\
\cline { 3 - 7 } & & 1670 & 2025 & 2430 & 2780 & 3180 \\
\hline 15 & Pakistan & 0.40 & 0.36 & 0.33 & 0.30 & 0.27 \\
15 & Spain & 0.44 & 0.40 & 0.37 & 0.34 & 0.31 \\
15 & Cuba & 0.35 & 0.32 & 0.29 & 0.27 & 0.25 \\
25 & Pakistan & 0.43 & 0.42 & 0.40 & 0.38 & 0.36 \\
25 & Spain & 0.56 & 0.51 & 0.46 & 0.42 & 0.37 \\
25 & Cuba & 0.39 & 0.36 & 0.33 & 0.31 & 0.29 \\
\hline
\end{tabular}

Cuba, wind velocities are higher in the winter period. This is a favourable situation since tomato prices are higher in the winter in the nearby US market. The opposite is seen, however, in Pakistan, where wind velocities are lower in the winter period when tomato prices are higher. These relationships affect the feasibility of using a wind pumping system.

\section{Conclusions}

A simple methodology was used for an economic assessment of different technologies for water pumping in greenhouses in Spain, Cuba and Pakistan (countries with different development levels and socioeconomic conditions), taking into account variables such as the wind resource available, the distance to the grid, the water tank storage volume required, and the tomato planting dates.

In all three scenarios, if a grid connection is already in place, installing wind pumps would not be economically wise.

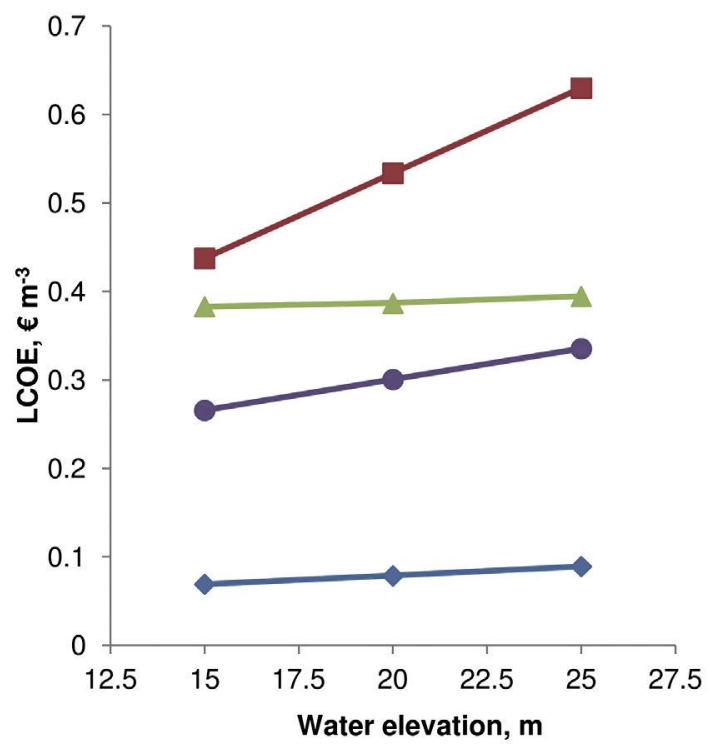

Fig. 1 - Levelised cost of energy for the different technologies studied as a function of the elevation for a $10,000 \mathrm{~m}^{2}$ greenhouse in Spain with a connection to the grid in place. [ grid connected, $\square$ Wind pump, $\triangle$ PV pump, - diesel pump]. 


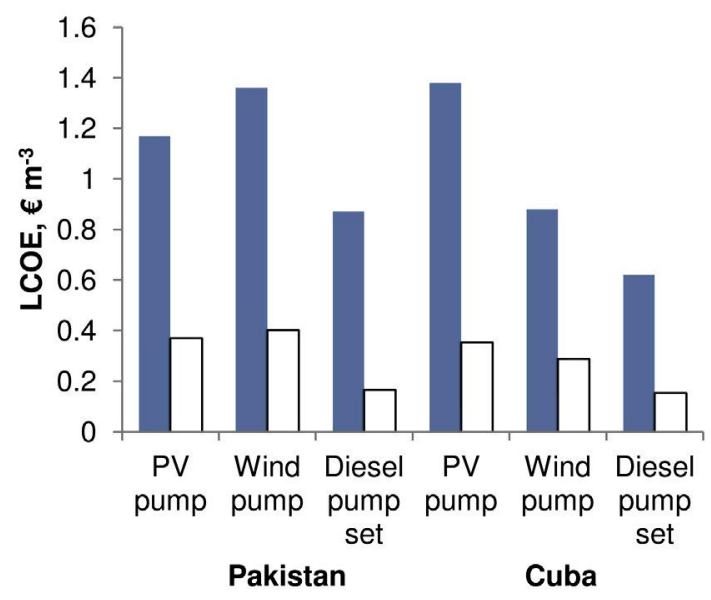

Fig. 2 - Levelised cost of energy $\left(€ \mathrm{~m}^{-3}\right.$ ) associated with different technologies and different greenhouse sizes in Pakistan and Cuba (no present electricity supply). [ greenhouse $1000 \mathrm{~m}^{2}, \square$ greenhouse $10,000 \mathrm{~m}^{2}$ ].

The need for a water storage tank, which guarantees the water supply when there is insufficient wind or sun, increases the investment costs beyond the point at which any economic return will be enjoyed.

The water elevation has a greater influence on the suitability of wind pump technology than on PV pumping technology. The distance to the grid is a key factor for considering the adoption of wind pumps for water irrigation in greenhouses, but the wind resources available and wind speed both have greater influence: a $10 \%$ increase in the average wind speed is equivalent to a $20 \%$ reduction in the distance to the grid.

The present results show that, generally, the critical factors to be considered when making decisions on energy

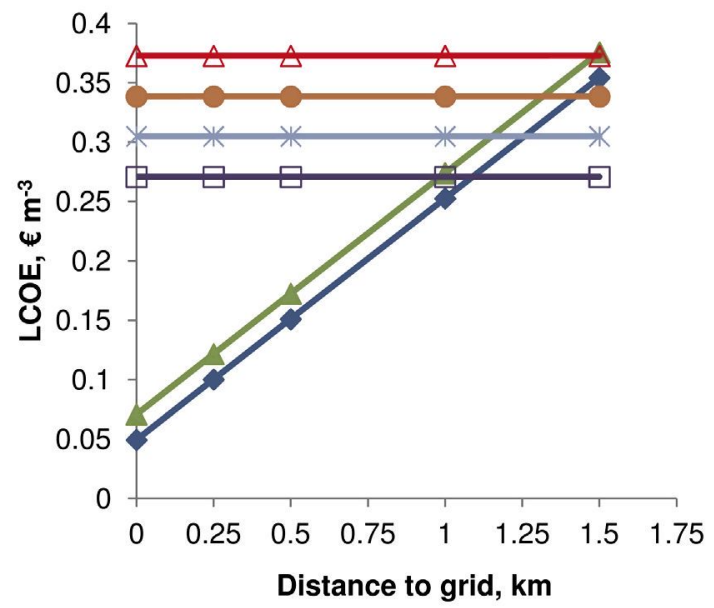

Fig. 3 - Impact of the wind speed (high and low wind situations, as defined in Section 2.1) on the levelised cost of wind pump-provided energy, and of distance to the grid on that of grid-supplied energy, for a $10,000 \mathrm{~m}^{2}$ greenhouse in Cuba. The greenhouse is deemed to have no present electricity supply. [ grid connected $H=15 \mathrm{~m}, \Delta$ grid connected $H=25 \mathrm{~m}, \square$ high wind $H=15 \mathrm{~m}$, high wind $H=25 \mathrm{~m}, *$ low wind $H=15 \mathrm{~m}, \Delta$ low wind $H=25 \mathrm{~m}]$.

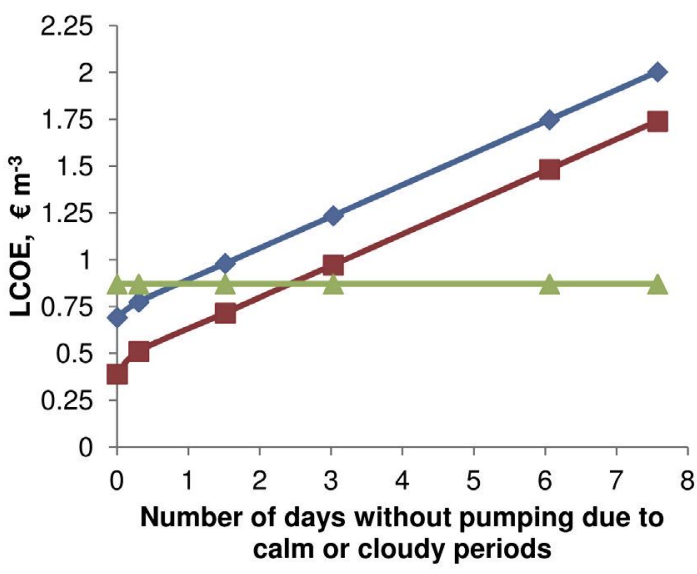

Fig. 4 - Levelised cost of energy as a function of the mean consecutive days without useful renewable energy (calm for wind power and cloudy for solar) for a $1000 \mathrm{~m}^{2}$ greenhouse in Pakistan, considering an elevation of $15 \mathrm{~m}$ and a water tank capable of storing the water required to cover such periods and the cost is for additional storage capacity to tide over that consecutive number of days. The greenhouse is deemed to have no prior electricity supply. [ Wind pump, $\square$ PV pump, $\triangle$ Diesel pumpset].

supply systems differ depending on the countries examined, although each case would have to be examined specifically. In Spain, the proximity of the electrical grid renders this choice of energy supply as the best alternative. In Pakistan, where wind resources are scarce and energy prices low, connection to the grid or the use of a diesel generator would seem to be the best choice. However, a careful analysis comparing diesel, grid and wind costs should be undertaken in areas where wind resources are not a limiting factor. Such an analysis could be undertaken using the methodology described in the present work. Finally, in Cuba, where wind resources are often good, the water elevation, the distance to the grid, and the water storage volume required would be the critical factors to be considered if wind pumping were to be used.

R E F E R E N C E S

Ajete, M., Bonet, C., Duarte, C., Vargas, M., \& Pérez, V. (2011). Criterios sobre la uniformidad de riego en cultivos protegidos de las provincias centrales [Criterion about the irrigation uniformity in greenhouses of the central provinces]. Revista Ciencias Técnicas Agropecuarias, 20(2), 47-50.

Al Malki, A., Al Amri, M., \& Al Jabri, H. (1998). Experimental study of using renewable energy in the rural areas of Oman. Renewable Energy, 14(1-4), 319-324.

Al-Smairan, M. (2012). Application of photovoltaic array for pumping water as an alternative to diesel engines in Jordan Badia, Tall Hassan station: case study. Renewable and Sustainable Energy Reviews, 16, 4500-4507.

Gamacho, F. (2003). Técnicas de producción en cultivos protegidos [Production techniques in protected cultivation]. Almería, Spain: Instítuto de Estudios de Cajamar.

Cammalleri, C., Agnese, C., Ciraolo, G., Minacapilli, M., Provenzano, G., \& Rallo, G. (2010). Actual evapotranspiration assessment by means of a coupled energy/hydrologic balance 
model: Validation over an olive grove by means of scintillometry and measurements of soil water contents. Journal of Hydrology, 392, 70-82.

Cammalleri, C., Ciraolo, G., Minacapilli, M., \& Rallo, G. (2013). Evapotranspiration from an olive orchard using remote sensing-based dual crop coefficient approach. Water Resources Management, 27, 4877-4895.

Chapagain, A. K., \& Orr, S. (2009). An improved water footprint methodology linking global consumption to local water resources: a case of Spanish tomatoes. Journal of Environmental Management, 90, 1219-1228.

Ghoneim, A. A. (2006). Design optimization of photovoltaic powered water pumping systems. Energy Conversion and Management, 47, 1449-1463.

IDAE. (2011). Análisis del recurso. Atlas eólico de España [Resource analysis. Wind Atlas of Spain]. Estudios Técnicos PER 2011-2020 $n^{\circ}$ 4. Madrid, España: IDAE.

Jaramillo, O. A., Borja, M. A., \& Huacuz, J. M. (2004). Using hydropower to complement wind energy: a hybrid system to provide firm power. Renewable Energy, 29, 1887-1909.

Koner, P. K. (1995). Optimization techniques for a photovoltaic water pumping system. Renewable Energy, 6(1), 53-62.

MAGRAMA (Ministerio de agricultura, alimentación y medio ambiente). (2012). Encuesta sobre superficies y rendimientos 2012 [National agricultural statistics: Land surface occupation and crop yields. Year 2012]. Secretaría general técnica. Subdirección general de estadística.

Mathew, S. (2006). Wind energy: Fundamentals, resource analysis and economics. Springer.

Mustafa, A. (2001). Solar water pumping: clean water for Sudan rural areas. Renewable Energy, 24, 245-258.

Parida, B., Iniyan, S., \& Goic, R. (2011). A review of solar photovoltaic technologies. Renewable and Sustainable Energy Reviews, 15, 1625-1636.

Peillón, M., Sánchez, R., Tarquis, A. M., \& García, J. L. (2013). The use of wind pumps for greenhouse microirrigation: a case study for tomato in Cuba. Agricultural Water Management, 120, 107-114.
Pino, M. A., Terry, E., León, A., \& Soto, F. (2003). Duración del ciclo biológico y sus fenofases para la variedad INCA-17 en sistemas de monocultivo y policultivo fuera del período óptimo [Duration of the life cycle and phenophases for INCA-17 variety in monoculture and polyculture systems outside the optimal period]. Cultivos Tropicales, 24(1), 5-8.

Ramos, J. S., \& Ramos, H. M. (2009). Solar powered pumps to supply water for rural or isolated zones: a case study. Energy for Sustainable Development, 13, 151-158.

Rodrigues, G. C., \& Pereira, L. S. (2009). Assessing economic impacts of deficit irrigation as related to water productivity and water costs. Biosystems Engineering, 103(4), 536-551.

Rodríguez, J. A., López, R., Carrillo, M. T., Montesinos, P., \& Camacho, E. (2009). Exploring energy saving scenarios for ondemand pressurised irrigation networks. Biosystems Engineering, 104(4), 552-561.

Short, W., Packey, D. J., \& Holt, T. (1995). A manual for the economic evaluation of energy efficiency and renewable energy technologies. National Renewable Energy Laboratory. U.S. Department of Energy.

U.S. Department of Energy. (2012). http:/www.nrel.gov/wind/ international_wind_resources.html Last accessed October 2013.

Vázquez, L. C. (2004). Evaluación de los molinos de viento Veleta y Delta Junior [Evaluation of Veleta and Delta Junior wind mills]. Ingeniería Hidráulica y Ambiental, XXV(2), 50-54.

Verstraeten, W. W., Veroustraete, F., \& Feyen, J. (2008). Assessment of evapotranspiration and soil moisture content across different scales of observation. Sensors, 8, 70-117.

Vick, V. D., \& Clark, R. N. (1996). Performance of wind electric and solar-PV water pumping system for watering livestock. Transactions of the ASME, 118, 212-216.

Viliers Aqua Engineering. (2013). http://www.poldawwindpumps. co.za/GeneralInformation.html Last accessed October 2013.

Walker, J., \& Jenkins, N. (1997). Wind energy technology. John Wiley \& Sons. 